\title{
OPTIMALISASI PELABUHAN TANJUNG PRIOK MENUJU PELABUHAN BERKELAS DUNIA
}

\author{
Yusuf Romadhon \\ Institut Ilmu Sosial dan Manajemen STIAMI \\ Email: yusufromadhonok@gmail.com
}

\begin{tabular}{|c|c|}
\hline ARTICLE INFO & ABSTRACT \\
\hline Keywords: & This paper wants to find out the optimization of the performance of Tanjung Priok port \\
\hline Optimization, & towards a world-class port. Based on 4 port performance indicators (financial, \\
\hline World Class Port, & operational, human resources and customers), it can be concluded that the port of \\
\hline \multirow[t]{3}{*}{ Tanjung Priok Port } & Tanjung Priok must continue to improve in order to become a world class port. This is \\
\hline & not easy because it must have the support of various existing stakeholders, not only PT \\
\hline & $\begin{array}{l}\text { Pelindo } 2 \text { as a port operator, but all parties related to it such as the Indonesian } \\
\text { Government, sub-subsidiary PT Pelindo 2, also PT Pelindo employees. }\end{array}$ \\
\hline
\end{tabular}

\section{PENDAHULUAN}

Pada saat ini banyak dari kesejahteraan dunia di produksi atau difasilitasi oleh pelabuhan laut dalam segala aktifitasnya. Pelabuhan merupakan lokasi dimana perdagangan, logisitik dan produksi menjadi satu kesatuan (Harry Geerlings,BartKuipers,Rob Zuidwijk, 2017).

Salah satu pelabuhan utama yang menjadi pintu gerbang konektivitas ekonomi nasional dan internasional di Indonesia adalah Pelabuhan Tanjung Priok. Saat ini Pelabuhan Tanjung Priok menjadi tulang punggung pembangunan nasional karena pelabuhan ini menangani lebih dari 30\% komoditi non migas Indonesia dan $50 \%$ dari seluruh arus barang yang keluar/masuk Indonesia melewati pelabuhan ini sehingga menjadikan Pelabuhan Tanjung Priok sebagai pelabuhan tersibuk di Indonesia.

Namun dalam perjalanan peran pelabuhan Tanjung Priok belum optimal sebagai pendorong pertumbuhan ekonomi nasional dan daerah seiring dengan lemahnya kinerja pelabuhan pelabuhan tanjung priok diantara pelabuhan lainnya di dunia.

Hal ini dapat dilihat dari 100 peringkat pelabuhan di dunia yang di keluarkan oleh AAPA (American Association of Port Authorities) selama kurun waktu 3 tahun terakhir yaitu tahun 2014 sampai dengan 2016. 
Tabel Peringkat Pelabuhan Tanjung Priok dalam 100 World Port Rankings

2014-2016

\begin{tabular}{|l|l|l|}
\hline Tahun & $\begin{array}{l}\text { Total Cargo } \\
\text { Volume }\end{array}$ & Rank \\
\hline 2014 & $51.200 \mathrm{MT}$ & 82 \\
\hline 2015 & 48.964 MT & 89 \\
\hline 2016 & $51.600 \mathrm{MT}$ & 85 \\
\hline
\end{tabular}

Sumber:AAPA

Dari tabel di atas dapat digambarkan bahwa peringkat pelabuhan tanjung priok mengalami penurunan peringkat dari tahun 2014 sampai dengan 2016 dalam kategori total cargo, bahkan untuk kategori Container Traffic tidak masuk dalam peringkat 100 besar pelabuhan terbaik dunia. Tulisan ini ingin mengetahui optimalisasi kinerja pelabuhan Tanjung Priok menuju pelabuhan kelas dunia.

\section{TINJAUAN PUSTAKA}

Menurut Undang-Undang No. 17 Tahun 2008 mengenai Pelayaran, pelabuhan adalah tempat yang terdiri atas daratan dan atau perairan dengan batas-batas tertentu sebagai tempat berkegiatan pemerintah dan perusahaan. Secara fisik, pelabuhan dipergunakan sebagai tempat kapal berlabuh, naik turun penumpang dan atau bongkar muat barang. Dengan demikian, pelabuhan pada umumnya berupa terminal dan tempat berlabuh kapal yang dilengkapi fasilitas keselamatan dan keamanan pelayaran serta kegiatan penunjang pelabuhan lain.

Sebagai salah satu prasarana transportasi, pelabuhan memiliki peran strategis untuk mendukung sistem transportasi karena menjadi titik simpul hubungan antar daerah/negara.

Selain itu, fungsi dasarpelabuhan adalahsebagai tempat perpindahan ke tingkat yang berbeda dengan kapal, sehingga memungkinkan pengiriman barang dari satu alat transportasi ke transportasi lainnya. Juga berfungsi sebagai penghubung simpul antara laut dan darat dan merupakan contoh nyata antar moda transportasi (Tarantola,dalam Van Roa 2013).

Secara konseptual, pelabuhan memiliki tiga fungsi strategis. Pertama, sebagai link atau mata rantai. Maksudnya, pelabuhan merupakan salah satu mata rantai proses transportasi dari tempat asal barang/orang ke tempat tujuan. Kedua, sebagai interface (titik temu), yaitu pelabuhan sebagai tempat pertemuan dua moda transportasi, misalnya transportasi laut dan transportasi darat. Ketiga, sebagai gateway (pintu gerbang), yaitu pelabuhan sebagai pintu gerbang suatu daerah/ negara.Dalam kaitan dengan fungsinya sebagai gateway, tidak terlalu mengherankan jika setiap kapal yang berkunjung ke suatu daerah/negara maka kapal itu wajib 
mematuhi peraturan dan prosedur yang berlaku di daerah/negara tempat pelabuhan tersebut berada (Lasse, 2015).

\section{Strategi Pelabuhan dalam Keunggulan Bersaing}

UNCTAD menyatakan bahwa ada dua strategi untuk bersaing di pelabuhanyang bisa ditempuh untuk mencapai keunggulan kompetitif, sebagai berikut:

1. Strategi Kepemimpinan Biaya

Pelabuhan tersebut dapat mencapai pengurangan biaya operasional, untuk menjadi pemasok dengan layanan biaya rendahpelanggan, sehingga mampu bersaing dengan pelabuhan lain, dan dapat dicapai melalui faktor-faktor berikut:
a. Pengurangan biaya perasional.
b. Pengurangan Biaya tenaga kerja.
c. Meningkatkan produktivitas tenaga kerja secara maksimal.
d. Optimalisasi Pemanfaatan aset tetap dan potensinya.
e. Fasilitas dan model dengan biaya rendah
f. Pendapatan dan biaya rendah.
g. Fasilitas dan pembedaan biaya pembayaran pelabuhan.
h. Manjaga pelanggan yang loyal
i. Layanan harga fleksibel

2. Diferensiasi Strategi Pelayanan

Strategi ini bergantung pada layanan yang berbeda dari pesaing lainnya, melalui penyediaan layanandengan nilai tambah tinggi, dan untuk mencapai diferensiasi dalam aktivitas tertentu yang pesaing tidak pernah tercapai, unikke pelabuhan tanpa yang lain, strategi ini bergantung pada faktorfaktor berikut:

a. Letak geografis

Elemen kedekatan pelabuhan ke pelabuhan utama dan jalur perdagangan, tingkat korelasi antara pelabuhan danpedalaman, volume jaringan transportasi dan komunikasi yang tersedia, dan pelabuhan pengolahan untuk menerima kapal ukuran besar.

b. Fasilitas

Tempat berlabuh khusus, terminal dan peralatan penanganan yang sesuai dan menggunakan teknologi tinggi pada Kinerja, fasilitas utama adalah yang paling penting dalam keberhasilan diferensiasi pada yang lain

c. Layanan

Layanan dianggap sebagai fungsi utama pelabuhan, pelabuhan tidak dapat mencapai tujuannya hanya melalui perencanaan pelabuhan, ukuran dan kebijakan diambil dan dicapai, untuk mengembangkan strategi diskriminasi sebagai penghubung utamapersyaratan pelanggan dalam 
kegiatan pelayanan terpadu, seperti layanan kargo yang, perbaikan kapal, pasokan, bunkering,layanan informasi untuk kapal, layanan kliring kargo dan tindak lanjut.

d. Kinerja

Pelabuhan mencapai diferensiasi untuk mendapatkan tingkat terendah untuk keluar masuk kapal, mengurangi waktu tinggal, memperbaiki layanan bagi pelanggan, dan memudahkan serta menyederhanakan penanganan dokumen. Strategi penarik yang memiliki target umum yang sama, yaitu diferensiasi yang didapat, dan mengurangi layanan

harga kepada pelanggan, strategi pertama untuk mendapatkan ini melalui tarif rendah, dan akses ke harga yang tepat untuk mendapatkanKepuasan pelanggan, namun strategi kedua berusaha untuk diferensiasi menghadirkan model bisnis yang unik ke pelabuhan tanpa yang lain. (UNCTAD, 1993 dalam Ahmed Shaheen, 2014).

\section{Kinerja Pelabuhan}

Indicator kinerja menurut UNCTAD setidaknya ada 4 dimensi sebagai pelabuhan modern yang harus di penuhi:

1. Keuangan, Mengukur kinerja keuangan sebuah pelabuhan semua layanan adalah target utama, meski secara keseluruhan yang tidak realistis karena banyak penyedia layanan pelabuhan beroperasi gabungan dari perusahaan swasta dan publik. Meski begitu, perhatian bisa difokuskan laporan kinerja keuangan entitas ini biasa digambarkan sebagai otoritas pelabuhan. Untuk melakukannya diperlukan untuk memiliki gambaran yang jelas tentang pendapatan dan biaya termasuk dalam lapoaran keuangan.

2. Operasional, Ini adalah yang terbesar dan paling umum diterapkan daerah dalam penilaian kinerja pelabuhan. Dengan kondisi data primer berkaitan dengan pergerakan kapal, orang, kargo dan informasi, tindakannya terdiri dari volume bergerak sehubungan dengan waktu, luas dan kapasitas teknis. Hal ini terutama berpusat pada mode kargo (product mix) dan dimensi spesial dari lokasi penanganan. Biasanya komparatif indikator mengacu pada tingkat penanganan kapal dan kargo, menghasilkan indikator efisiensi untuk ruang dan waktu. Dimensi ini merupakan tantangan tersendiri dalam membangun definisi yang biasa diterima.Scorecard kinerja port dalam fase selanjutnya akan juga mencakup dimensi operasional lainnya seperti energi, lingkungan dan keamanan. Mengidentifikasi penggunaannya teknologi berbasis Internet. Efisiensi drive juga akan ada dalam pengembangan kartu skor.

3. Sumber daya manusia, indikator ini sangat diminati oleh Program Manajemen Pelabuhan, mengingat bahwa tujuan utama Program adalah pengembangan sumber daya manusia untuk lebih ditingkatkan penyampaian layanan pelabuhan dan fasilitasi perdagangan, dan pada gilirannya kesejahteraan ekonomi nasional. Pengumpulan data awal berfokus pada angka yang dipekerjakan oleh kategori luas, sifat pengaturan kelembagaan tenaga kerja semacam itu sebagai keseimbangan gender permanen atau sementara, dan kejadian waktu yang hilang akibat pemogokan atau lainnyapenghentian terkait tenaga kerja. Biaya relatif jenis tenaga kerja sebagai proporsi semua biaya dan / atau pendapatan adalah ukuran 
komparatif yang berguna. Jenis ini tenaga kerja berasal dari otoritas pelabuhan, bongkar muat (pribadi dan publik) dan sumber daya santai. Indikator yang berkaitan dengan efisiensi dapat dihitung pada dasar komparatif yang masuk akal.

4. Pelanggan, Ini adalah area yang tidak tercakup di awal fase, karena datanya lebih mahal dan bermasalah Meskipun demikian, bisa dibagi menjadi kepuasan pelanggan, pangsa pasar dengan mode kargo, efektivitas layanan seperti model.

Tujuan analisis portofolio adalah untuk mengidentifikasiposisi pasar masing-masing pelabuhan dalam hal matrikspada gambar 6, yang melacak perubahan dari waktu ke waktupangsa pasar pelabuhan dalam kaitannya dengan pertumbuhan pasar.Mengadaptasi pendekatan ini akan memberikan dasar untuk mengukurkinerja dalam hal pasar pelabuhan danposisi kompetitif relatif masing-masing produk port. Itumatriks adalah snapshot satu periode dan tidak mengambilakun perubahan dari waktu ke waktu. Analisis dinamis, termasuk pengukuran untukBeberapa periode pada setiap port, akan menggambarkan bagaimanaport berjalan ke atau dari pemain bintangkategori. Dengan meng-hubungkan periode waktu yang dipilih dengan kebijakanreformasi dan / atau pergeseran strategis, kinerja kebijakan bisadiukur dan dibandingkan

Gambar 1 Flow Chart Kinerja Pelabuhan Scorecard

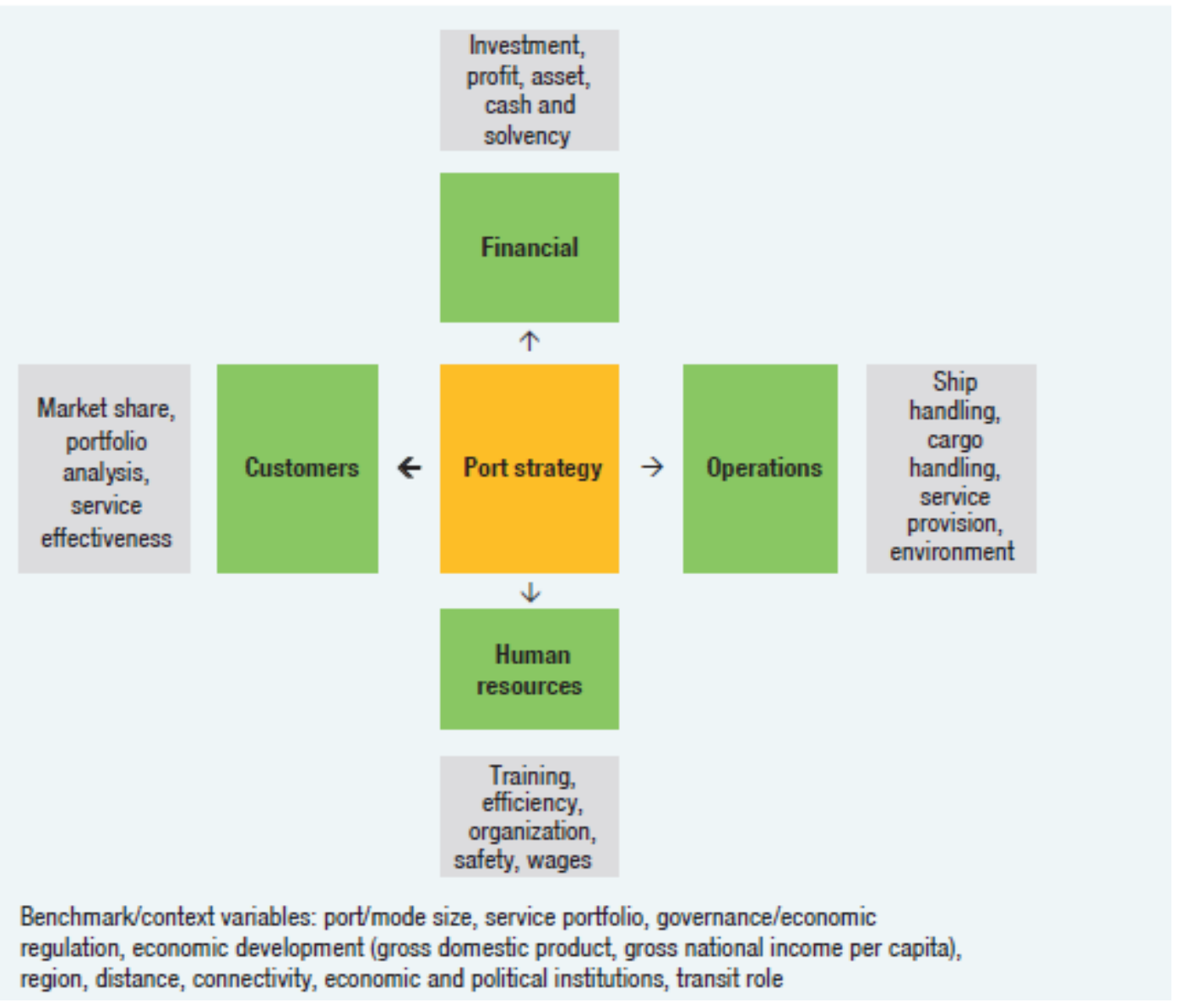

Sumber: R Kaplan, and D Norton, 1996 dalam UNCTAD, 2016 


\section{METODOLOGI}

Metode yang digunakan penulis dalam melakukan penelitian ini yaitu dengan melalui pendekatan kualitatif. Data yang dikumpulkan penelitian dengan pendekatan kualitatif bukan berupa angka-angka melainkan data tersebut berasal dari naskah wawancara, catatan lapangan, dokumen pribadi, catatan, memo dan dokumen resmi lainnya.Selain itu juga, dengan penelitian kualitatif, penulis berusaha membangun makna mengenai suatu fenomena berdasarkan pandangan-pandangan dari para narasumber.Jenis penelitian deskriptif kualitatif yang penulis gunakan dalam penelitian ini adalah studi kasus. Menurut Yin (Mukhtar, 2013: 35) yang dimaksud dengan studi kasus adalah salah satu metode penelitian ilmu sosial.Metode penelitian ini sangat cocok untuk digunakan manakala seorang penulis ingin mengungkap sesuatu dengan bertolak pada pertanyaan "How atau Why".

\section{HASIL DAN PEMBAHASAN}

\section{Kondisi Kinerja Pelabuhan Tanjung Priok}

\section{Keuangan}

Berdasarkan laporan keuangan tahun 2016, PT Pelindo 2 sebagai pengelola pelabuhan tanjung priok membukukan pendapatan sebanyak Rp7,62 triliun dalam sembilan bulan 2017 atau meningkat 19,6\% secara tahunan Tren positif tersebut salah satunya didorong pertumbuhan trafik petikemas dan nonpetikemas masing-masing 10,8\% dan 3,1\%. Hal ini berarti secara keuangan PT Pelindo cukup baik dan sehat dalam mengelola Pelabuhan Tanjung Priok.

\section{Operasional}

Dwelling Time Pelabuhan Tanjung Priok masih 3,9 hari. Ketua Serikat Pekerja PT Jakarta International Container Terminal (JICT) Nova Sofyan Hakim menyebutkan, waktu bongkar muat petikemas di Pelabuhan Tanjung Priok yang dikelola oleh PT Pelindo II (Persero) masih memakan waktu yang cukup lama yakni 3,9 hari. "Pelindo II bilang dwelling time sudah 2,7 hari, ternyata faktanya masih 3,9 hari. 2,7 hari itu cuma dwelling time ekspor, kalau dengan impor 3,9 hari," ujar Nova saat dihubungi. Kompas.com,Kamis(23/3/2017).

\section{Sumber Daya Manusia}

Guna menunjang kelancaran kegiatan bongkar muat di Pelabuhan Tanjung Priok, maka Koperasi Karya Sejahtara Tenaga Kerja Bongkar Muat (KS-TKBM) Pelabuhan Tanjung Priok mengadakan sertifikasi dan uji kompetensi bagi sekitar 2.000-an buruh. Hasilnya sekitar 20 persen buruh pelabuhan atau tenaga kerja bongkar muat (TKBM) saat ini sudah dan mengantongi sertifikasi profesi bongkar muat di pelabuhan. Pernyataan ini disampaikan oleh Suparmin, Sekretaris KS-TKBM dalam pelaksanaan uji kompetensi dan sertifikasi profesi buruh Pelabuhan Priok pada Jumat (31/3 )di kantor KSTKBM Tanjung Priok (Intipesan, 31 maret 2017). Tentunya pembekalan sertifikasi ini untuk menunjang kinerja operator pelabuhan tanjung priok. 


\section{Pelanggan}

Pelayanan pelanggan yang diberikan PT Pelindo 2 dan operator-operatornya masih banyak mengalami keluhan dari pelanggan. Salah satu contohnya Pelayanan Inaportnet di Pelabuhan Tanjung Priok Jakarta masih banyak dikeluhkan oleh perusahaan pelayaran dan keagenan kapal. Sejumlah perusahaan keagenan kapal mengatakan pelayanan menggunakan sistem Inaportnet di pelabuhan tersibuk di Indonesia itu membutuhkan waktu lebih dari lima jam (translogtoday, 3 mei 2017)

\section{SIMPULAN}

Berdasarkan hasil temuan di lapangan mengenai 4 indikator kinerja pelabuhan Maka dapat disimpulkan bahwa pelabuhan tanjung priok masih harus terus berbenah guna bisa menjadi pelabuhan yang berkelas dunia. Hal ini tidak mudah karena harus mendapat dukungan dari berbagai stake holder yang ada. Tidak hanya PT Pelindo 2 sebagai operator pelabuhan, tapi semua fihak tekait seperti Pemerintah Indonesia, subkon PT Pelindo 2, juga karyawan PT Pelindo.

\section{REFERENSI}

AAPA (American Association of Port Authorities) World Port Rankings 2014-2016

Ahmed Shaheen and Hany Mahmoud The Competitive Advantage of Seaports and Applied to the East Port

Said - Port Said, Abd El-All Maritime College, Arab Academy for Science and Techonology, Alexandria, Egypt, International Journal of Research in Applied, Natural and Social Sciences (IMPACT: IJRANSS) ISSN(E): 2321-8851; ISSN(P): 2347-4580 Vol. 2, Issue 11, Nov 2014, 111-120

Harry Geerlings,dkk. Ports and Networks: Strategies, Operations and Perspectives

Lasse, D.A. Manajemen Kepelabuhanan.Jakarta: Raja GrafindoPersada. 2015

Van Roa,dkk Ports: definition and study of types, sizes and business models, (Spain), Journal of Industrial Engineering and Management, 6(4), 1055-1064, 2013.

http://www.intipesan.com/sertifikasi-tenaga-kerja-bongkar-muat-pelabuhan-tanjung-priok/ Kompas.com,Kamis,23/3/2017.

UNCTAD PORT MANAGEMENT SERIES - Volume 4, 2016 